\title{
The Buccal Myomucosal Flap for Reconstruction of the Oral Cavity Cancers
}

\author{
(1) Burak Karabulut, (1) Hakan Avcl
}

Department of Otolaryngology, University of Health Sciences, Kartal

Dr. Lütfi Kırdar Training and Research Hospital, İstanbul, Turkey

Submitted: 06.03.2020 Accepted: 15.03.2020

Correspondence: Burak Karabulut, Sağlık Bilimleri Üniversitesi

Kartal Dr. Lütfi Kırdar Eğitim ve Araştırma Hastanesi Kulak Burun

Boğaz Hastalıkları Kliniği İstanbul, Turkey

E-mail:kbbturk@yahoo.com

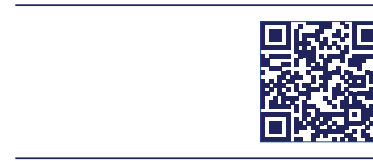

Keywords: Buccal myomucosal flap; oral cavity tumors; reconstruction.

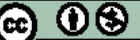

This work is licensed under a Creative Common Attribution-NonCommercial 4.0 International License.

\begin{abstract}
Objective: We aimed to review our data about the functional outcomes of the buccinator myomucosal flap used for head and neck reconstruction after oncologic ablative surgery.
\end{abstract}

Methods: Retrospective chart analysis was performed of 15 patients between the ages 52 and 78 years (mean age 66 years) who had buccinator myomucosal flaps for oral cavity reconstruction after tumor ablation. All the resections and reconstructions were performed by the first author (BK) at two tertiary referral centers. The demographic feature of the patients, anatomical subsites of the cancer, operation type, flap raising time, total operation time, blood loss during flap harvesting, wound problems and other postoperative complications, decannulation time and postoperative oral feeding time were collected from the patients' medical charts.

Results: One patient had minimal distal flap loss. There was no need for additional surgery for this patient. Two patients had partial wound dehiscence, which was resutured in the operating theatre. The donor sites were closed primarily in all cases. One of the patients had wound dehiscence in donor site which healed by secondary intention. Mean flap size was $7 \times 3.2 \mathrm{~cm}$. All flaps needed a second operation for pedicle separation due to the pedicled flap nature. All separations of pedicles were performed using sedation and adequate analgesia in operating theatre without general anesthesia. Mean separation time was 12 days after the first surgery. Three patients had tracheostomy and the mean decannulation time was three days for those. Soft diet was started in the postoperative 2 nd day in all patients. However, mean postoperative oral feeding time without any nasogastric tube assistance was five (3-9 days) days. Mean flap harvesting time was 35 minutes (25-49 minutes). Mean intraoperative blood loss during flap harvesting was $25 \mathrm{ml}(20-40 \mathrm{ml})$.

Conclusion: Buccinator myomucosal flap should be in the armamentarium of every head and neck surgeon for oral cavity reconstruction.

\section{INTRODUCTION}

Oral cavity reconstruction following resection of neoplasm is a challenging issue for the head and neck oncologic surgery team. There are a variety of reconstructive options available for optimum functional and cosmetic results. Free flaps are at the top of the reconstruction ladder. However, it needs a highly skilled microvascular surgery team. It is not always possible to arrange both the ablative and microvascular reconstruction team at the theatre in a practical daily routine. In addition to this arrangement problem, some patients are not good candidates for free flap reconstruction. Peripheral vascular disease, smoking, prior radiotherapy to recipient site are some of the relative contraindications for free flap procedures. The patients having free flaps also need extensive postoperative flap monitoring and longer hospital stays. Therefore, patients having critical systemic health issues may need local and regional flaps other than free flap options. Pectoralis major muscle has been used extensively as the first choice of pedicled flaps in head and neck surgery. However, the bulky nature of this pedicled flap limits its usage specifically in early staged tumors of head and neck area.

The buccinator muscle is a quadrangular-shape muscle. The buccinator musculomucosal flap is an axial-pattern flap which contains buccal mucosa and buccinator muscle. ${ }^{[1,2]}$ This flap can be based on either buccal or fascial arteries. The donor site is very close to the oncologic surgical field. This eliminates the usage of additional surgical dressing or preparation for reconstruction intraoperatively. This flap can be harvested easily and it provides perfect flexibility and versatility. The flap has good color and texture in nature. The donor site can be primarily closed with minimal morbidity. In this study, we aimed to review our data about the functional outcomes of the buccinator myomucosal flaps used for head and neck reconstruction after oncologic ablative surgeries. 


\section{MATERIALS AND METHODS}

Retrospective chart analysis was performed on 15 patients between the ages of 52 and 78 years (mean age 66 years) who had buccinator myomucosal flaps for oral cavity reconstruction after tumor ablation. All the resections and reconstructions were performed by the first author (BK) at two tertiary referral centers. The demographic feature of patients, anatomical subsites of cancer, operation type, flap raising time, total operation time, blood loss during flap harvesting, wound problems and other postoperative complications, decannulation time and postoperative oral feeding time were collected from the patients' medical charts (Table I).

In all cases, the buccinator myomucosal flap was the first choice for reconstruction. Totally the study includes II cases with tongue cancers, two cases with hard palate cancers and 2 cases with cancers of the floor of the mouth.

\section{Surgical technique}

The flap was designed in the rectangular fashion on the buccal mucosa (Fig. I). The limits were oral commissure anteriorly, parotid duct superiorly and pterygomandibular raphe posteriorly. Inferior limit depends on the size of defectl. Flap was raised from anterior to the posterior direction in the loose areolar plane between the buccinator muscle and the buccopharyngeal fascia. The small branches from the fascial artery were ligated. The dissection was processed through pterygomandibular raphe till the neurovascular bundle was identified. The donor site was closed primarily. The flap pedicle was not interposed with the molar teeth. The vascular pedicle was divided in the $2^{\text {nd }}$ week after primary surgery.

\section{RESULTS}

There was no total flap loss in our study. One of the patients had minimal distal flap loss and there was no need for additional surgery for this patient. Two patients had partial wound dehiscence that was resutured in the operating theatre. The donor sites were closed primarily in all cases. One of the patients had wound dehiscence in the donor site, which healed by secondary intention. Mean flap size was $7 \times 3.2 \mathrm{~cm}$. All flaps needed a second operation for pedicle separation due to the pedicled flap nature. All separations of pedicles were performed under sedation and adequate analgesia in operating theatre without general anesthesia. Mean separation time was 12 days after the first surgery. Three patients had tracheostomy and the mean decannulation time was three days for those. Mild oral rinse for oral hygiene was started for all patients in postoperative day I. All patients had a nasogastric feeding tube for enteral nutrition. Soft diet was started in the postoperative 2 nd day in all patients. However, mean postoperative oral feeding time without any nasogastric tube assistance was 5 (3-9 days) days. Mean flap harvesting time was 35 minutes (25-49 minutes). Mean intraoperative blood loss during flap harvesting was $25 \mathrm{ml}(20-40 \mathrm{ml})$.

\section{DISCUSSION}

Buccinator myomucosal flap is perfused mainly by the buccal artery. The flap was firstly described by Bozola et al. ${ }^{[1]}$ Its color and nature perfectly match with mucosal defects of the oral cavity. The opportunity of the primary closure of the donor site and the absence of external scar are other advantages of the flap. ${ }^{[3]}$ It can be planned as a pedicled flap or island flap. Zhao stated that this flap should not be chosen when facial artery and vein are at risk during neck dis-

Table I. Demographic findings of 15 patients

\begin{tabular}{|c|c|c|c|c|c|c|}
\hline Gender & Age & Tumor side & $\begin{array}{l}\text { Neck dissection } \\
\text { (level) }\end{array}$ & $\begin{array}{l}\text { Intraoperative } \\
\text { blood loss }\end{array}$ & Complication & $\begin{array}{c}\text { Tracheotomy tube } \\
\text { removal (day) }\end{array}$ \\
\hline Male & 52 & Tongue & $I-V$ & 25 & Partial dehiscence & 3 \\
\hline Female & 68 & Floor of mouth & $\mathrm{I}-\mathrm{V}$ & 30 & None & - \\
\hline Male & 72 & Tongue & $\mathrm{I}-\mathrm{V}$ & 40 & None & 3 \\
\hline Male & 59 & Tongue & $\mathrm{I}-\mathrm{V}$ & 25 & None & - \\
\hline Female & 55 & Hard palate & I-IV & 20 & None & - \\
\hline Male & 70 & Tongue & I-V & 20 & None & - \\
\hline Male & 77 & Tongue & $\mathrm{I}-\mathrm{V}$ & 20 & None & 3 \\
\hline Male & 68 & Tongue & $\mathrm{I}-\mathrm{V}$ & 25 & Partial dehiscence & - \\
\hline Male & 66 & Hard palate & I-IV & 30 & None & - \\
\hline Male & 64 & Tongue & $\mathrm{I}-\mathrm{V}$ & 40 & None & - \\
\hline Male & 69 & Tongue & $I-V$ & 20 & None & - \\
\hline Male & 78 & Floor of mouth & $I-V$ & 20 & Distal flap loss & - \\
\hline Male & 68 & Tongue & $\mathrm{I}-\mathrm{V}$ & 20 & None & - \\
\hline Male & 66 & Tongue & $I-V$ & 20 & None & - \\
\hline Male & 65 & Tongue & $I-V$ & 20 & None & - \\
\hline
\end{tabular}



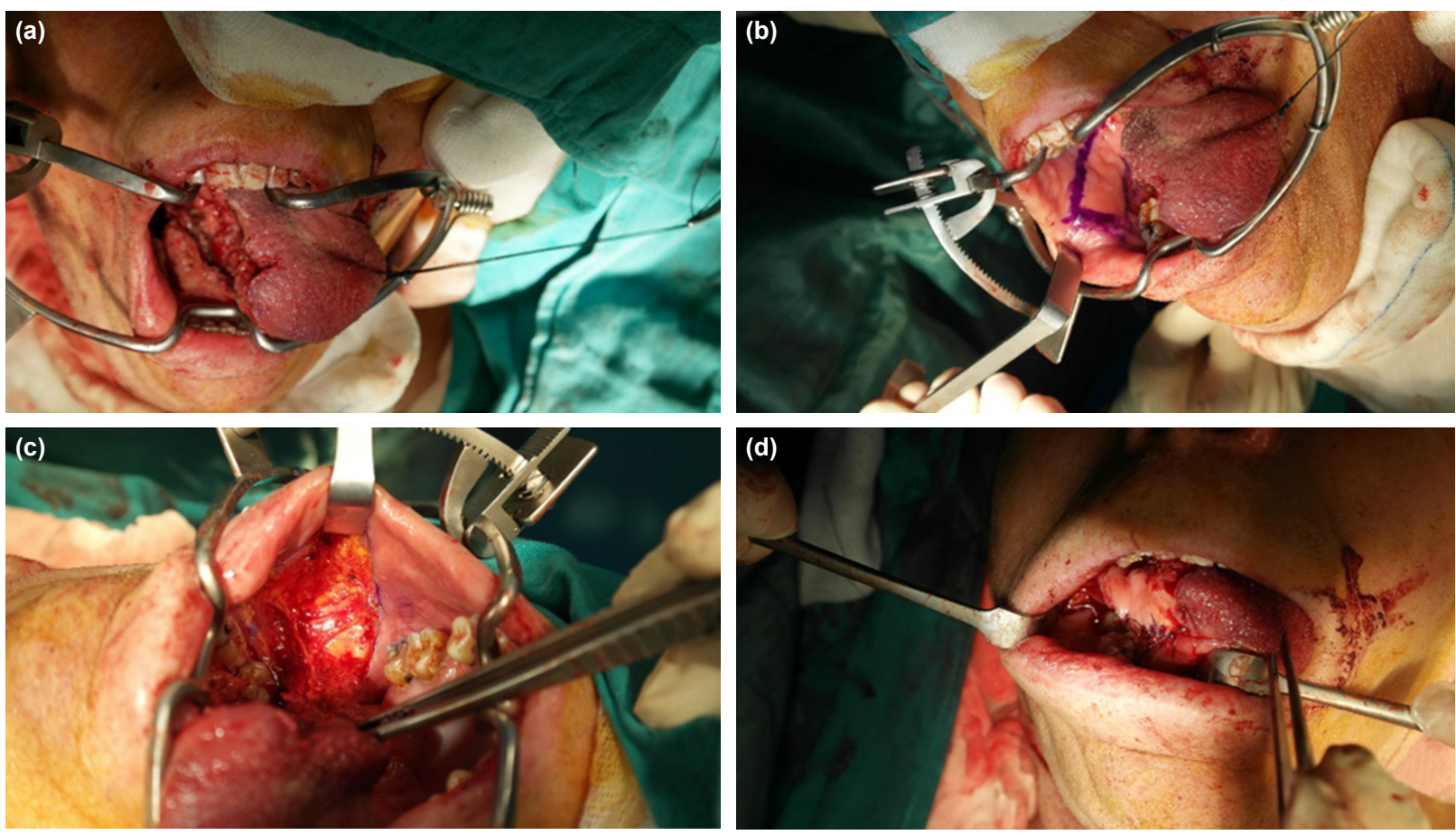

Figure 1. The seventy-two-year-old man underwent right partial glossectomy and ipsilateral neck dissection for squamous cell carcinoma. (a) Right partial glossectomy defect. (b) Right posteriorly based buccal myomucosal flap preparation (c) Flap was raisen showing pterygomandibular raphe and buccal pad, which is the posterior border of the flap elevation. (d) The flap was sutured to the defect.

section. ${ }^{[4]}$ However, buccal myomucosal flap is supplied by buccal artery, which is a branch of internal maxillary artery. [I] Thus, the facial artery injury or division during neck dissection is not a contraindication for this flap usage. Woo et al. performed neck dissection of level I-II-III in eight patients of II without any compromise in the vascular supply of the flap. ${ }^{[5]}$ We also had an ipsilateral neck dissection of level III-III in all patients $(n=15)$ without any problem. Therefore, we suggest that the facial artery is not an issue for buccal myomucosal flap surgery. This may be a superiority of this flap to facial artery myomucosal artery (FAMM) flap, whose vascular supply comes from the facial artery. We suggest that the buccal myomucosal flap can be a better option than the FAMM flap when the facial artery is at risk during the neck dissection.

Some authors suggested using Doppler imaging to identify the buccal artery intraoperatively. ${ }^{[6,7]}$ However, we were not able to show the benefits of Doppler imaging. Firstly, it was not easy to use Doppler in the mucosal side of the oral cavity. It was time-consuming and it did not provide any additional data for flap planning because the neurovascular bundle was in the precise localization in pterygomandibular raphe in all patients. We did not encounter any problem to identify the neurovascular bundle intraoperatively. Thus, we do not recommend routine identification of the buccal artery by Doppler imaging system intraoperatively.

Bardazzi et al. studied the flap in $\mathbf{2 7}$ tongue tumors. They stated that 7 of 27 patients had xerostomia after radiotherapy. ${ }^{[8]}$ In our study, 3 of 15 patients had postoperative radiotherapy. None of them had xerostomia.
Tracheostomy was performed in three cases to secure the airway. We decannulated all patients in postoperative $3^{\text {rd }}$ day without any problem. The postoperative edema can be a problem, specifically in tongue cancers. One should not hesitate to perform tracheostomy. The edema mostly resolves in a few days and it is easy to decannulate those patients.

Mean postoperative oral feeding time without any nasogastric tube assistance was five days. Soft diet was started in postoperative $2^{\text {nd }}$ day in all patients. The patients had mild discomfort in the buccal side where the flap was harvested during oral feeding. However, this was temporary in all cases. Oral rinse with chlorhexidine gluconate was used in all patients for proper oral hygiene. We did not have any infectious problems in any patient. Ahn used a visual analog scale to evaluate swallowing in 22 patients who had buccal myomucosal flap. ${ }^{[9]}$ Scale points were ranging from 0 to 10 , with higher scores indicated better swallowing function. Mean scale score was 9.6, which is quite high. We did not perform any objective swallowing measurements in these patients. However, none of our patients had difficulty in starting oral feeding.

Bleeding was not an issue in this flap harvesting. Our patients' mean blood loss was $25 \mathrm{ml}$. There are some perforator branches that arise from the fascial artery during flap harvesting. The authors reported using hemoclips for the bleeding control of these branches. Fine bipolar coagulation was enough in our cases. We did not have any bleeding problems in the postoperative period. 
Partial wound dehiscence was seen in two patients. We believe that it was due to the natural high volume of sputum secretion of the oral cavity. We resutured those cases in the operating theatre. However, we did not perform any additional procedures for those patients because the flap division was performed simultaneously in those cases.

Woo et al. reported that they used the flap in a dentate patient without any complication. However, this data was only from one patient. ${ }^{[5]}$ The data need to be reevaluated in further studies with more patients outcome. Patients having especially ipsilateral second and third lower molars have the potential risk of pedicle injury by biting. Thus, we do not use this flap in dentate patients in our daily practice.

The buccinator myomucosal flap may play a critical role in the reconstruction of the oral cavity after oncologic ablative surgery. The donor site is in the primary surgical field and can be closed primarily in most of the cases. Flap harvesting and reconstruction are easy for a head and neck reconstructive surgeon. The pedicle division should be done in the postoperative $2^{\text {nd }}$ week. We believe that this flap should be in the armamentarium of every head and neck surgeon.

Ethics Committee Approval

Approved by the local ethics committee (date: 02.01.2020, no: $2020 / 5$ |4/|69/2).

Peer-review

Internally peer-reviewed.

Authorship Contributions

Concept: B.K.; Design: B.K.; Supervision: B.K., H.A.; Materials: B.K., H.A.; Data: B.K.; Analysis: H.A.; Literature search: H.A.; Writing: B.K.; Critical revision: H.A.

Conflict of Interest

None declared.

\section{REFERENCES}

1. Bozola AR, Gasques JA, Carriquiry CE, Cardoso de Oliveira M. The buccinator musculomucosal flap: anatomic study and clinical application. Plast Reconstr Surg 1989;84:250-7. [CrossRef]

2. Carstens MH, Stofman GM, Hurwitz DJ, Futrell JW, Patterson GT, Sotereanos GC. The buccinator myomucosal island pedicle flap: anatomic study and case report. Plast Reconstr Surg 1991;88:39-52.

3. Szeto C, Yoo J, Busato GM, Franklin J, Fung K, Nichols A. The buccinator flap: a review of current clinical applications. Curr Opin Otolaryngol Head Neck Surg 2011;19:257-62. [CrossRef]

4. Zhao Z, Zhang Z, Li Y, Li S, Xiao S, Fan X, et al. The buccinator musculomucosal island flap for partial tongue reconstruction. J Am Coll Surg 2003;196:753-60. [CrossRef]

5. Woo SH, Jeong HS, Kim JP, Park JJ, Ryu J, Baek CH. Buccinator myomucosal flap for reconstruction of glossectomy defects. Otolaryngol Head Neck Surg 2013;149:226-31. [CrossRef]

6. Van Lierop AC, Fagan JJ. Buccinator myomucosal flap: clinical results and review of anatomy, surgical technique and applications. J Laryngol Otol 2008;122:181-7. [CrossRef]

7. Rahpeyma A, Khajehahmadi S. The posterior-based buccinator myomucosal flap (Bozola's flap). Eur Ann Otorhinolaryngol Head Neck Dis 2017;134:293-4. [CrossRef]

8. Bardazzi A, Beltramini GA, Autelitano L, Bazzacchi R, Rabbiosi D, Pedrazzoli M, et al. Use of Buccinator Myomucosal Flap in Tongue Reconstruction. J Craniofac Surg 2017;28:1084-7. [CrossRef]

9. Ahn D, Lee GJ, Sohn JH. Reconstruction of oral cavity defect using versatile buccinator myomucosal flaps in the treatment of cT2-3, N0 oral cavity squamous cell carcinoma: Feasibility, morbidity, and functional/oncological outcomes. Oral Oncol 2017;75:95-9. [CrossRef]

\section{Oral Kavite Tümörlerinde Rekonstrüktif Amaçlı Bukkal Miyomukozal Flep Kullanımı}

Amaç: Kliniğimizde oral kavite kanseri nedeni ile cerrahi yapılan ve rekonstrüksiyonda bukkal miyomukozal flep kullanılan hastaların dosya kayıtları incelenerek flebin fonksiyonel sonuçları incelendi.

Gereç ve Yöntem: Kliniğimizde 2016 Temmuz-2020 Şubat dönemi içerisinde oral kavite skuamöz hücreli kanseri nedeni ile ameliyat edilen ve bukkal miyomukozal flep rekonstrüksiyonu yapılan 15 hastanın dosya kayıtları incelendi. Hastaların demografik özellikleri, tümörün yerleşim yeri ve evresi, flebin hazırlanma süresi, flebe bağlı intraoperatif kanama miktarı ameliyat sonrası yaşanılan komplikasyonlar, varsa dekanülasyon süreleri, nazogastrik sonda ile yardım olmaksızın oral beslenme süreleri kayıtlarda araştırıldı.

Bulgular: Hastalarımızın yaş ortalaması 66 idi (dağılım, 52-78 yıl). On beş hastanın I3'ü erkek ikisi kadın idi. Oral kavite tümörlerinin I I'i dil, ikisi ağız tabanı ve ikisi de sert damak kaynaklı idi. Ortalama flep uzunluğu $7 \times 3.2 \mathrm{~cm}$ idi. Üç hastaya trakeostomi açıldı ve hepsi ameliyat sonrası üçüncü günde dekanüle edildi. Tüm hastalara ameliyat sonrası ikinci günde yumuşak diyet başlandı. Ameliyat sonrası ortalama beşinci günde hastalar nazogastrik sonda yardımı olmaksızın beslenmeye başlandı. Flep kaldırma süresi ortalama 35 dakika (25-49 dakika) idi. Ortalama kanama miktarı $25 \mathrm{ml}(20-40 \mathrm{ml})$ idi. İki hastada flepte parsiyel yara yeri açılması ve bir hastada parsiyel kısmı flep kaybı gözlendi.

Sonuç: Bu bulgular ışı̆ı̆nda bukkal miyomukozal flep özellikle oral kavite kanser defektlerinin rekonstrüksiyonunda baş boyun cerrahlarının akılda tutması gereken seçeneklerden birisidir. Flebin primer cerrahi sahada olması, teknik olarak hızlı ve basit hazırlanabilmesi avantajları pediküllü bir flep olması nedeni ile yaklaşık iki hafta sonra pedikülünün kesilmesinin gerekliliği dezavantajları içerisinde sayılabilir.

Anahtar Sözcükler: Bukkal miyomukozal flep; oral kavite tümörleri; rekonstrüksiyon. 